\title{
Reproductive timing and larval dispersal of intertidal crabs: the predator avoidance hypothesis
}

\author{
Sincronía reproductiva y de dispersión larval en cangrejos intermareales: la hipótesis \\ anti-depredador
}

JOHN H. CHRISTY

Smithsonian Tropical Research Institute, Apartado 2072, Balboa, Ancón, Republica de Panamá, or Unit 0948, APO AA 34002, USA; e-mail: christyj@ naos.si.edu

\begin{abstract}
Many intertidal and shallow water crabs have strong reproductive cycles and migratory larvae. Females release larvae near the time of high water of the larger amplitude nocturnal tides during the semilunar or lunar cycles. Newly hatched larvae move quickly at night toward and into the sea where, weeks later, they develop to megalopae that then ride nocturnal flood tides inshore and up estuaries to settle in adult habitats. It was first thought that crabs might time larval release so that larvae will become megalopae when they can ride the larger amplitude spring flood tides to adult habitats. This idea was rejected when it was found that were was no change in the timing of hatching during the breeding season by several estuarine species that would compensate for the decrease in the larval development period as the water temperature increased. In addition, megalopae moved up-stream at night but not on the largest spring flood tides. Attention shifted to the possible value to larvae of leaving the estuary quickly to avoid high temperatures, low salinities or stranding. This idea was not supported when it was found that species on open coasts exhibit the same reproductive patterns as do estuarine species. Alternatively, by moving quickly to the ocean at night larvae may best escape visual planktivorous fishes that are especially abundant in shallow areas. This predator avoidance hypothesis has been broadly supported: species with larvae that are cryptic, spiny and better protected from predation lack both strong reproductive cycles and larval migration. The mechanisms that promote precise reproductive timing have been little studied. Evidence is presented that female fiddler crabs may adjust the timing of fertilization to compensate for variation in incubation temperatures that would otherwise induce timing errors. However, crabs on colder coasts, as in Chile, apparently do not exhibit biweekly or monthly cycles of larval release. The consequences of this for adults and larvae have yet to be explored.
\end{abstract}

Key words: larval release, larval dispersal, crabs, reproductive timing, plankton, predation.

\section{RESUMEN}

Muchos cangrejos intermareales y de aguas poco profundas tienen ciclos reproductivos marcados y larva migratoria. Las hembras liberan sus larvas durante las mareas nocturnas más altas, cuyas amplitudes coinciden con ciclos lunares o semilunares. Las larvas recién eclosionadas se mueven rápidamente mar adentro durante la noche donde, semanas después, alcanzan el estado de megalopa. En este estado, las larvas utilizan las mareas nocturnas para acercarse a la costa y al interior de los estuarios para establecer su hábitat en estado adulto. Inicialmente se pensó que estos crustáceos liberan sus larvas en forma simultánea de modo que al momento de alcanzar el estado de megalopa serían capaces de utilizar las mayores amplitudes de marea para movilizarse a su hábitat en estado adulto. Esta idea ha sido refutada por la observación de que especies de zonas costeras abiertas presentan patrones reproductivos similares a aquellas de estuarios. Como hipótesis alternativa, se planteó que las larvas abandonan rápidamente los estuarios durante la noche para escapar de depredadores visuales como peces planctívoros, abundantes en aguas poco profundas. La hipótesis antidepredador ha recibido apoyo considerable: especies con larvas visualmente crípticas, con espinas y mejor protegidas de los depredadores carecen de ciclos reproductivos marcados y migración larval. Los mecanismos que causan esta sincronía reproductiva han sido poco estudiados. Documento evidencia en cuanto a que las hembras del cangrejo violinista ajustarían el momento de la fertilización de sus huevos para evitar variaciones en la temperatura de incubación que producirían errores de sincronía. Sin embargo, cangrejos de costas frías como en Chile aparentemente no muestran ciclos bi-semanales o mensuales de liberación de sus larvas. Las consecuencias de ello para las larvas y los adultos requiere ser examinado.

Palabras clave: liberación larval, dispersión larval, cangrejos, sincronía reproductiva, plancton, depredación. 


\section{INTRODUCTION}

Many intertidal crabs (Morgan \& Christy 1995) and other marine organisms that live in shallow water (Morgan 1995) have semilunar or lunar reproductive cycles. Most hypotheses to explain the adaptive significance of these cycles belong to one of two general classes. Synchrony hypotheses propose that there are direct density-dependent benefits to concurrent reproduction among individuals (Ims 1990) and that the timing of reproduction is unimportant. Marine organisms may reproduce on lunar-related schedules simply because variation in tidal amplitude and other physical factors with the lunar cycle is pervasive in intertidal and shallow water habitats making these factors reliable timers for synchrony. Synchrony hypothesis often have been applied to marine organisms that shed their gametes directly into the sea (Levitan 1998). Individuals that spawn at the same time and near to others in a local population (e.g., the black sea urchin Diadema antillarum Philippi: Lessios 1991, Levitan 1991) may benefit because their gametes have a better chance of uniting to form zygotes than do the gametes of individuals who spawn when few others do. Other density-dependent modes of selection also may favor synchrony. For example, spawning synchrony among dozens of species of scleractinian corals on the Great Barrier Reef (Babcock et al. 1986) may be favored because predators become sated on abundant gametes or zygotes thus increasing the per capita survival rates of these otherwise vulnerable life stages.

In contrast, timing hypotheses propose that individuals benefit by reproducing at a particular phase of a physical or biological cycle that is correlated with the lunar and tidal cycles (Morgan \& Christy 1995). In this case, synchrony is an incidental consequence of individual reproductive timing and confers no particular fitness benefits because the causes of selection for reproducing at a particular time are density independent. There is now considerable evidence that a timing hypothesis best explains the adaptive significance of the timing of larval release by intertidal crabs (Morgan 1995, Morgan \& Christy 1994, 1995); most crabs release their larvae at night, when few planktivorous fishes are feeding in the shallow waters where adults live, and on large amplitude ebb tides so that larvae are transported rapidly seaward to safer waters where they develop. I will refer to this as the predator avoidance hypothesis. The purpose of this paper is to outline the progression of hypotheses and their tests that have shaped our understanding of this feature of crab behavior and life history and lead to this hypothesis. Although predation on larvae appears to be the primary cause of selection for precise reproductive timing in intertidal crabs, we know very little about the behavioral and physiological mechanisms that allow such timing. Because the rate of embryonic development is temperature dependent, I suggest that mechanisms that compensate for potential timing errors due to temperature variation during incubation may be important. I will present preliminary data indicating that such a mechanism may be operating in a tropical fiddler crab that experiences seasonal temperature variation due to upwelling events. Finally, I will suggest possible directions for research on this topic that may be profitably undertaken on the coast of Chile. Nomenclature follows Crane (1975) for the fiddler crabs and Rathbun (1918,1930) for the other brachyuran genera.

\section{THE UPSTREAM-TRANSPORT FOR SETTLEMENT HYPOTHESIS}

Interest in non-seasonal, lunar or semilunar reproductive cycles of crabs was stimulated by behavioral studies of fiddler crabs in Trinidad (Crane 1958, von Hagen 1970), Panama (Pacific coast, Zucker 1978) and the US Gulf (Christy 1978) and Atlantic (Wheeler 1978, DeCoursey 1979, Bergin 1981) coasts. In most studies, reproductive activity at the population level followed a semilunar schedule. Uca pugilator on the west coast of Florida provides a clear example (Christy 1978). Like many fiddler crabs in the Americas (de Rivera \& Vehrencamp 2001), male $U$. pugilator court from and defend breeding burrows to which females come for mating and in which they incubate their eggs (Christy 1982a, 1983). Males were synchronized in their reproductive activity, courting for 4 to 6 consecutive days twice each month when most females were sexually receptive and chose mates (Christy 1978). Unlike males, individual females reproduced at most once each month with about equal numbers of females breeding during alternate semilunar periods. About two weeks after choosing a mate, females emerged from their incubation burrows and released larvae, often near the time of a late afternoon or early evening high tide (Kellmeyer \& Salmon 2001). During this study on the Gulf Coast of Florida, these tides occurred around the times of the quarter moons.

Research on the dispersal of crab larvae in the lower Chesapeake Bay, a very large estuary on the Atlantic coast of the North America, had 
shown that (1) larvae generally move toward the sea during development and (2) fiddler crab larvae move deeper during development where net tidal flows are in the landward direction (Sandifer 1973, 1975). Laboratory studies of larval development (e.g., Wheeler 1978, Vernberg \& Vernberg $1975)$ gave estimates of about 15 days from hatching to the megalopa, and about another week for the megalopa to become competent to settle. Hence, hatching in the Florida population on the neap tides might result in the production of competent megalopae about three weeks later during spring tides when landward flood tide current velocities should be greatest. This lead to the upstream transport hypothesis: crabs may time larval release so that megalopae will be transported at biweekly maximum rates by higher velocity currents during larger amplitude spring flood tides (Christy 1978, Wheeler 1978). This would be beneficial because it would increase the rate that megalopae encounter and settle in adult habitats and decrease mortality as megalopae move into and up estuaries where predators abound.

This hypothesis produced specific testable predictions based on two features of the life histories of crabs in the temperate zone: reproductive seasonality and temperature dependent larval development rates. On the Atlantic Coast of the USA and on warm temperate coasts generally, crabs begin breeding when the water and sediment temperatures are several degrees cooler and the duration of larval development is several days longer compared to the late summer and fall when reproduction ends. If the upstream transport hypothesis is correct, then, at the onset of reproduction, crabs should release larvae several days before the time they release in the warmer months so that megalopae become competent during spring tides regardless of the seasonally changing water temperature. More specifically, there should be a seasonal, temperature-dependent change in the phase between the larval release and the spring tide cycles and the rate of this change should match the seasonal, temperature-dependent rate of change in the development period from hatching to competency. Finally, megalopae should settle in adult habitats primarily during spring tides.

These predictions were tested during a twoyear study in the North Inlet Estuary, South Carolina (Christy 1982b, Christy \& Stancyk 1982). From the start of breeding by three species of fiddler crabs in May to the end of breeding in October, water temperature increased from about 22 to $28^{\circ} \mathrm{C}$. As expected, the larval development period to the megalopae stage decreased from about 19 to 14 days, but the timing of larval release relative to the lunar and spring tide cycles did not change. Instead, these fiddler crabs, two intertidal grapsid crabs, a shallow water subtidal xanthid and a commensal pinnotherid all released larvae on the days of the biweekly cycle, around the time of the full and new moons, with the largest amplitude nocturnal ebb tides. Consequently, newly hatched crab larvae were rapidly transported seaward and exported from this estuary to the coastal ocean (Christy \& Stancyk 1982). Megalopae returned episodically into and up the estuary by riding nocturnal flood tides, but not during spring tides as predicted (Christy 1982b, Christy \& Morgan 1998).

\section{THE DOWN-STREAM TRANSPORT HYPOTHESES: ABIOTIC CAUSES OF MORTALITY}

The North Inlet study and studies of the timing of larval release by intertidal crabs at other locations world-wide (see Forward 1987, Morgan 1995, Morgan \& Christy 1995) showed that most species release larvae near the time of high tide on relatively large amplitude tides that peak in the early evening, typically near the time of the full and new moons. Consequently newly hatched larvae move rapidly at night toward the sea on the ebbing current. Convergence on this pattern by so many species in different families and with different adult ecologies suggested that species-specific modes of selection on adults probably were not shaping reproductive timing (Christy 1982b). Instead, a number of hypotheses were proposed to explain why rapid nocturnal seaward movement may benefit newly hatched larvae. Some invoked selection from abiotic causes of larval mortality including high temperatures in shallow pools in intertidal creeks during the day (Dollard 1980, Bergin 1981), low salinities during low tide (Saigusa 1981) and stranding on expansive intertidal mud and sand flats (Morgan 1987a).

These hypotheses could be tested by comparing the timing of hatching by species that produce larvae that are and are not resistant to high temperatures, low salinities or exposure and desiccation. Saigusa (1981) found that two grapsids living along streams relatively far from the sea produced larvae that died quickly in fresh water; both species released larvae when they would be most rapidly transported to the sea. Another sympatric grapsid that lived closer to the ocean and whose larvae exhibited greater tolerance to low salinity lacked strong cycles of larval release. Although larval sensitivities to low salinities are the reverse of what one would expect based on the location of adult populations on the salinity gra- 
dient, these results are consistent with the idea that the timing of larval release allows larvae to escape lethal low salinities. In contrast, a study by Morgan (1987a) showed that fiddler crab larvae of Uca minax, a species that times release so that larvae emigrate quickly from estuaries, were more rather than less resistant to low salinity and high temperature compared to mud crab larvae (Rhithropanopeus harris) that do not emigrate. I know of no larger systematic studies that would help resolve this issue probably because resistance to abiotic stressors is associated with the evolution of terrestriality, abbreviated development, unusual breeding environments, and low or no planktonic dispersal (Diesel et al 2000). Another approach is to examine the timing of larval release by crabs on an exposed rocky coast where larvae are not exposed to high temperatures, low salinities and stranding. If mortality due to these abiotic factors has shaped reproductive timing then species on exposed coasts should not release larvae near the time of high tide on the larger amplitude nocturnal ebb tides in the biweekly spring-neap cycle.

A study of the timing of larval release by three xanthid crabs (Christy 1986) that live together in the rocky intertidal zone on the Pacific coast of the Republic of Panama revealed that two species fit the pattern shown by estuarine crabs. The other species did not, as discussed below. These results do not support the proposition that larval mortality due to abiotic stressors has selected for the common temporal pattern of larval release. Instead we need to seek a mode of selection that may affect diverse species across a relatively broad geographic range of intertidal and shallow water habitats.

\section{The predator-avoidance hypothesis}

Additional studies of reproductive timing and larval dispersal showed that, with rare exceptions (Cronin 1982) the larvae of intertidal estuarine crabs did not stay in their estuary of origin during development, a previously popular notion (Epifanio 1988). Instead of being retained, larvae migrated; they emigrated from the estuary by riding nocturnal ebb tides to the coastal ocean where they developed for several weeks and then immigrated as megalopae by riding nocturnal flood tides (Christy \& Morgan 1998). How could this migration improve individual fitness when it was likely to increase the chance that larvae would be lost due to dispersion at sea (Strathman 1982)?

The answer was first suggested by the exceptional larval morphology, behavior and dispersal of Rhithropanopeus harrisi, a small estuarine xanthid that does not exhibit the biweekly cycle of larval release so common among other estuarine crabs (Forward 1987). The newly hatched larvae of this species are distinguished by their unusually long spines that might confer some protection from predators, especially planktivorous fish (Christy 1982). In addition, by using complex vertical migration rhythms (Cronin $\&$ Forward 1982) larvae of this species are retained in the upper estuary near adult habitats throughout development (Cronin 1982). The correlation between continuous reproduction, retention and apparently protective spines suggested that the timing of larval release to coincide with large amplitude nocturnal ebb tides may be an adaptation to allow vulnerable, newly-hatched larvae to escape planktivorous fish that are especially abundant nearshore and less common in the coastal ocean (Christy 1982, Morgan 1990). Indeed, in an elegant set of experiments, Morgan (1987b, 1989, 1990) showed that the spines of $R$. harrisi are a very effective defense against planktivorous fish and that the small spines of the larvae of fiddler crabs and other species that have marked reproductive cycles and emigrate from estuaries render them vulnerable to predation from the same estuarine predators.

A very similar line of evidence favoring the predator escape hypotheses came from testing the adaptive significance of another kind of unusual larval trait. In the study of reproductive timing on an exposed coast in Panama, Eurypanopeus planus, one of three xanthids, did not exhibit biweekly reproductive cycles. It released larvae during both the day and the night and its tidal phase timing was very variable. Eurypanopeus planus larvae are virtually identical in size and spination to the larvae of the other two xanthids Cataleotodius taboganus and Xanthodius sternberghii that showed strong biweekly cycles with larval release on the large amplitude tides just after dusk. However the chromatophores of the later two species are red-orange at hatching while those of E. planus are yellow-green and black. This suggested that the color of zoeae, as well as their spines, may affect their vulnerability to visually feeding diurnal planktivorous fish (Christy 1986). Experimental tests of this idea showed that, indeed, yellow-green was cryptic and protective whereas red-orange was conspicuous and made larvae highly vulnerable to fish predation during the day (Morgan \& Christy 1996). In general, interspecific comparisons, within and across tidal regimens, of the relationships between tidal amplitude, tidal and day/night timing and the sizes and defenses (color and morphol- 
ogy) of larvae have proven very productive (Morgan \& Christy 1994, 1996, 1997, Hovel \& Morgan 1997) and have provided broad support for the predator avoidance hypothesis.

\section{MECHANISMS}

Although the adaptive significance of the timing of larval release by crabs now seems relatively well understood, and studies of the physiological and behavioral mechanisms that allow precise tidal and day/night timing have begun (e.g., DeVries \& Forward 1991), far less is know about the mechanisms regulating longer-term biweekly or monthly timing (but see Saigusa 1988). Larval release ends the period of embryonic development and maternal brood care which begins with ovulation and fertilization. Clearly, biweekly timing must be under the control of the female reproductive cycle about which we know surprisingly little in brachyuran crabs. Females must time mate searching, mate choice, mating and ovulation and fertilization so that development begins at the appropriate time. There is some evidence that female fiddler crabs Uca pugilator change the time that they ovulate and fertilize eggs relative to when they choose a mate in the biweekly cycle. If they choose "early," a day or two before the peak mating day, they delay ovulation, and if they choose "late," they ovulate immediately (Christy 1978). However, as for invertebrates generally, embryonic development rates are temperature dependent in crabs (e.g., Wear 1974). Hence, control of the timing of ovulation and the onset of development will lead to accurate timing of hatching only if incubation temperatures do not vary substantially. Movement between thermal microenvironments, even vertical movements of just a few centimeters within a burrow, may be an important element of maternal care in many intertidal crabs, not only to keep eggs safe from thermal extremes but so that development proceeds on time. However, this interesting possibility has yet to be studied in any cyclic species.

In some species, behavioral regulation of incubation temperatures may not be an option because females incubate from relatively fixed positions in burrows, cavities or other microhabitats. This is the situation for many fiddler crabs that incubate in small cavities in burrows underground where sediment temperature varies in complex ways as the day/night and tidal cycles change phase. In some species incubation chambers are at the bottoms of burrows provided by males (de Rivera \& Vehrencamp 2001). In this case we expect females to assess the suitability of bur- rows for incubation when they are choosing mates. Mate choice based on burrow features, including a minimum depth requirement, has been demonstrated in Uca pugilator (Christy 1983) and Uca annulipes (Backwell \& Passmore 1996). By choosing relatively deeper burrows females may be selecting incubation sites in which the temperature varies relatively little.

A recently completed study of the timing of reproduction by the fiddler crab Uca musica shows an unexpected degree of flexibility. This species has marked biweekly reproductive cycles in which the intensity of male courtship, measured as the number of courting males and the time they spend signaling most intensively to females, exactly matches the female mate choice cycle (Christy et al. 2001). Individual males court for several consecutive days each biweekly period and on one or two days, when courting most intensely, they build sand hoods by their burrows; these structures are very attractive to females (Christy et al. 2002). Females visit sequentially about 20 males and finally choose one by staying in his burrow where the pair then mates. About a day later, after ovulation and fertilization, the male leaves the female in an underground chamber at about $20 \mathrm{~cm}$ depth. The chamber is about $3 \mathrm{~cm}$ in diameter and is not connected to the surface or to other cavities. She stays there and incubates her eggs until they are ready to hatch whereupon she ascends to just below the surface and releases her larvae into the water at high tide at night.

At the study site in the upper Bay of Panama in the tropical Eastern Pacific, the offshore trade winds during January through April cause upwelling events that last a few days to a week or more. During upwelling the water temperature drops from an average of about 28 to 20 to $22{ }^{\circ} \mathrm{C}$ (De Croz \& Robertson 1997) which produces a correlated, but smaller amplitude change in the slightly warmer temperatures of the sediment where females are incubating (J.H. Christy unpublished results). A study of the effect of temperature on embryonic development rates showed that, over the appropriate temperature range, development rates increased about one day for each degree that the temperature decreased. In the warmer wet season, females incubate for about 13 to 14 days while development lasts 18 to 19 days when the sediment is cooled by the cooler dry season sea temperatures (Fig 1). A concurrent study of tidal and day/night timing of larval release showed that most females release larvae near the time of high tide of the larger amplitude nocturnal tides in the biweekly tidal amplitude cycle. How does $U$. musica release larvae on the appropriate days when there is a seasonal change 


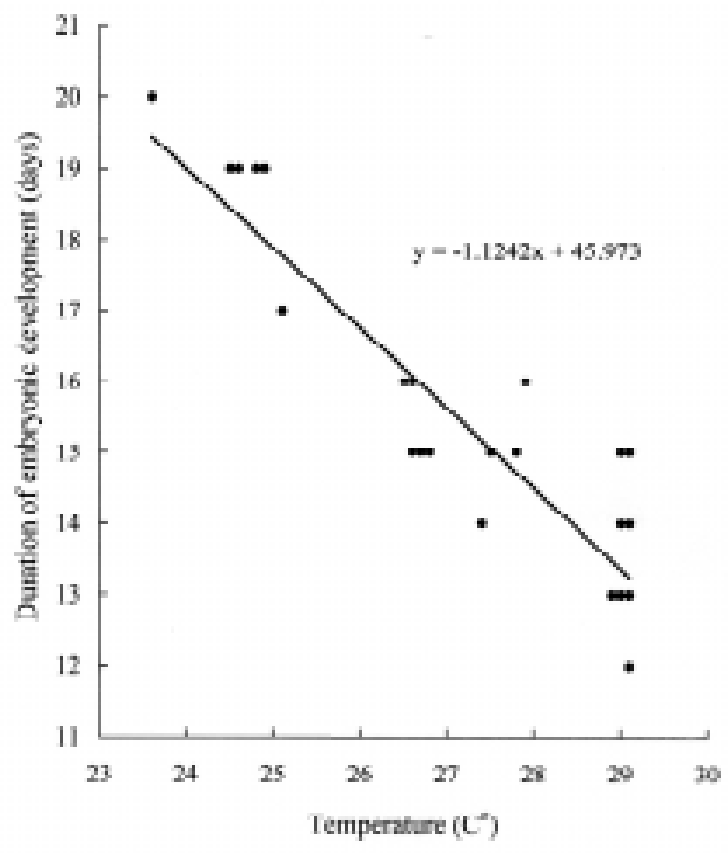

Fig. 1: The duration of embryoninc development of Uca musica over the natural range in environmental temperature during incubation. Females mated and ovulated in the field. They were collected the day they ovulated or the day after, brought to the lab and housed individually in containers with a small amount of water in outdoor flow-through seawater tables where they and their eggs were exposed to natural variation in seawater temperatures. The temperature assigned to each female is the average of the daily mean water temperature. The duration of incubation is the number of days from fertilization to hatching.

Duración de desarrollo embrionario de Uca musica en relación al rango natural temperatura ambiente registrado durante la incubación. Las hembras copularon y ovularon en condiciones naturales. Las hembras fueron recolectadas el día de ovulación o un día después, fueron transportadas al laboratorio y mantenidas individualmente en contenedores con flujo de agua de mar a la intemperie de modo que tanto ellas como sus huevos estuvieron expuestos a las variaciones naturales de la temperatura del agua de mar. La temperatura asignada a cada hembra correspondió al promedio de la temperatura promedio diaria. La duración del período de incubación correspondió al número de días transcurrido entre la fertilización y la eclosión.

of about 5 degrees in incubation temperatures and a change of about 5 days in the duration of embryonic development?

We monitored the intensity of male courtship by counting the number of sand hoods that were built in a fixed area. The number of hoods is directly correlated with the intensity of mate choice and ovulation (Christy et al. 2001) and therefore can be used as a proxy measure (with the addition of about 1 day) for the timing of the onset of incubation. We found about a 5 day change in the phase relationship between the reproductive cycle and the spring tide cycle over the months spanning the dry season drop in sea temperature (Fig 2). This suggests that adults changed when they began reproduction to compensate for the effects of the change in incubation temperatures on embryonic development so that larvae were released on the appropriated days with large amplitude ebb tides throughout the season.

Although we can expect behavioral adaptations to compensate for the potentially deregulating effects of temperature variation on reproductive timing, there undoubtedly are limits to what is possible. In the early spring on the Atlantic coast of North America temperature can vary substantially from day to day and the timing of larval release by estuarine crabs is notoriously "noisy" at the beginning of the season (Wheeler 1978, Dollard 1980, Christy \& Stancyk 1982) Another general pattern that may be related to temperature is the apparent absence of biweekly reproductive cycles in intertidal crabs on the Pacific coast of North America (S.G. Morgan personal communication) where, as on the coast of Chile, the sea temperature varies less and never becomes as warm as it does on the Atlantic coast. Incubation may take several weeks on coasts with cool air and water temperatures (e.g., Wear 1974, Baeza \& Fernández 2002). Small relative changes in development rate due to slight environmental variation would result in changes of several days in when embryos are ready to be released as larvae. Hence, precise biweekly timing of hatching may be unattainable by intertidal and shallow water crabs on colder coasts. How do these crabs reduce predation on newly hatched larvae? Do they release larvae only at night near the time of high tide, but on tides of all amplitudes? Are their larvae better defended morphologically or by cryptic colors? Are eggs smaller and clutch sizes larger to compensate for lower larval survival rates? Or, are clutches smaller and eggs larger leading to larger larvae that can better escape predation by gape-limited planktivorous fishes (Morgan 1987)? A comparison of the planktivorous fish communities and the reproductive timing, larval traits, and life history characteristics of common crab taxa along a latitudinal and temperature gradient on the coast of Chile (e.g., Lardies \& Castilla 2001) might provide new insights into whether and how suites of characters have evolved in response to selection by predation on newly hatched larval. 


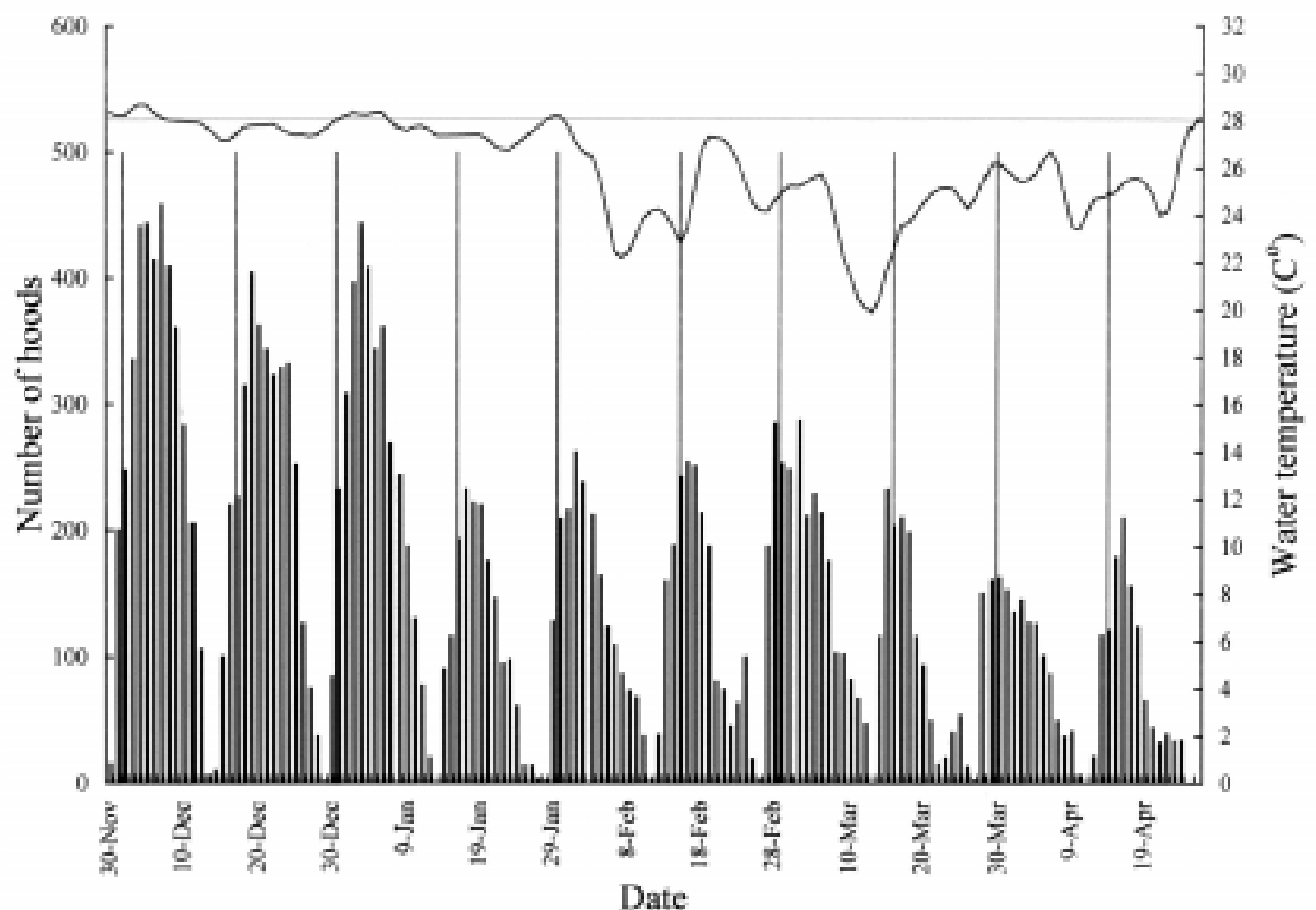

Fig. 2: Biweekly reproductive cycles of the fiddler crab Uca musica over a five month period that spanned the dry season and cold water upwelling in the upper Bay of Panama, December, 1999 - April, 2000. The number of courting males in a fixed area that built sand hoods, a courtship signal that is very attractive to females, was counted daily. The number of hoods is strongly positively correlated with the number of females who choose mates on a given day $(\mathrm{r}=0.88, \mathrm{P}<0.05)$. The daily temperature is the three-day running average of the mean daily temperature (hourly measurements) in shallow water near the study site. The tall vertical lines mark the dates of the full and new moons, the syzygies. The mating peak falls 5 to 6 days after the syzygies in December and January when it is relatively warm, and then shifts to 0 to 1 day after the syzygies when it is relatively cool in February and March. This phase shift in the onset of reproduction may compensate for the 4 to 5 day longer embryonic development at cool temperatures so that females release larvae on the larger amplitude nocturnal ebb tides over the natural seasonal range in incubation temperatures.

Ciclos reproductivos bi-semanales del cangrejo violinista Uca musica en un periodo de 5 meses que incluyó la temporada seca y con surgencias frías en el sector superior de la Bahía de Panamá, entre diciembre de 1999 y abril de 2000. Se evaluó el número de machos cortejantes en un área fija diariamente a través de contar el número de "capuchas" de arena, una estructura de cortejo que es atractiva para las hembras. El número de capuchas se correlaciona positivamente con el número de hembras que seleccionaron pareja cada día $(\mathrm{r}=0,88 ; \mathrm{P}<0,05)$. La temperatura diaria corresponde al promedio de la temperatura promedio diaria durante de tres días seguidos (medidas a intervalos de una hora) en aguas poco profundas y cercanas a la situación de muestreo. Las líneas altas verticales indican las fechas de luna llena y nueva, o "syzygies". El máximo de aparejamiento se registró 5 a 6 días después de los "syzygies" entre diciembre y enero cuando es relativamente cálido, y luego 0 a 1 día después de los "syzygies" cuando es relativamente frío entre febrero y marzo. Este cambio de fase en el inicio de la reproducción podría compensar los 4 a 5 días adicionales de desarrollo embrionario de los huevos expuestos a temperaturas más frías de modo que las hembras serían capaces de liberar sus larvas durante las mayores mareas nocturnas y a lo largo del rango estacional natural de temperaturas de incubación.

\section{LITERATURE CITED}

BAEZA JA \& M FERNÁNDEZ (2002) Active brood care in Cancer setosus (Crustacea: Decapoda): the relationship between female behaviour, embryo oxygen consumption and the cost of brooding. Functional Ecology 16: 241-251.
BABCOCK RC, GD BULL, PL HARRISON, AJ HEYWARD, JK OLIVER, CC WALLACE \& BL WILLIS (1986) Synchronous spawnings of 105 scleractinian coral species on the Great Barrier Reef. Marine Biology 90: 379-394. 
BACKWELL PRY \& N PASSMORE (1996) Time constraints and multiple choice criteria in the sampling behaviour and mate choice of the fiddler crab Uca annulipes. Behavioral Ecology and Sociobiology 38: 407-416.

BERGIN ME (1981) Hatching rhythms in Uca pugilator (Decapoda: Brachyura). Marine Biology 63:151-158.

CHRISTY JH (1978) Adaptive significance of reproductive cycles in the fiddler crab Uca pugilator: a hypothesis. Science 199: 453-456.

CHRISTY JH (1982a) Burrow structure and use in the fiddler crab, Uca pugilator (Bosc). Animal Behaviour 30: 687-694.

CHRISTY JH (1982b) Adaptive significance of semilunar cycles of larval release in fiddler crabs (genus $U c a$ ): test of an hypothesis. Biological Bulletin 163: 251263.

CHRISTY JH (1983) Female choice in the resource-defense mating system of the sand fiddler crab, Uca pugilator. Behavioral Ecology and Sociobiology 12: 169-180.

CHRISTY J H (1986) Timing of larval release by intertidal crabs on an exposed shore.Bulletin of Marine Science 39: 176-191.

CHRISTY JH \& SE STANCYK (1982) Timing of larval production and flux of invertebrate larvae in a wellmixed estuary. In: Kennedy VE (ed) Estuarine comparisons: 489-503. Academic Press, New York, New York, USA.

CHRISTY JH \& SG MORGAN (1998) Estuarine immigration by crab postlarvae: mechanisms, reliability and adaptive significance. Marine Ecology Progress Series 174: 51-65.

CHRISTY JH, PRY BACKWELL \& S GOSHIMA (2001) The design and production of a sexual signal: hoods and hood building by male fiddler crabs Uca musica. Behaviour 138: 1065-1083.

CHRISTY JH, PRY BACKWELL, S GOSHIMA \& T KREUTER (2002) Sexual selection for structure building by courting male fiddler crabs: an experimental study of behavioral mechanisms. Behavioral Ecology 13: $366-374$

CRANE J (1958) Aspects of social behavior in fiddler crabs with special reference to Uca maracoani (Latreille). Zoologica, New York 43: 113-130.

CRONIN TW (1982) Estuarine retention of the larvae of the crab Rhithropanopeus harrisii. Estuarine, Coastal and Shelf Science 15: 207-220.

CRONIN TW \& RB FORWARD (1982) Tidally timed behavior: effects on larval distributions in estuaries. In: Kennedy VS (ed) Estuarine comparisons: 505520. Academic Press, New York, New York, USA.

D'CROZ L \& DR ROBERTSON (1997) Coastal oceanographic conditions affecting coral reefs on both sides of the isthmus of Panama. In: Lessios HA \& IG Macintyre (eds) Proceedings of the Eighth International Coral Reef Symposium 2: 2053-2058. Smithsonian Tropical Research Institute, Balboa, Republic of Panama.

DECOURSEY PJ (1979) Egg-hatching rhythms in three species of fiddler crabs. In: Naylor E \& RG Hartnoll (eds) Cyclic phenomena in marine plants and animals: 399-406. Pergamon Press, Oxford, United Kingdom.
DERIVERA CE \& SL VEHRENCAMP (2001) Male versus female mate searching in fiddler crabs: a comparative analysis. Behavioral Ecology 12: 182-191.

DE VRIES MC \& RB FORWARD (1991) Mechanisms of crustacean egg hatching: evidence for enzyme release by crab embryos. Marine Biology 110: 281-291.

DIESEL R, CD SCHUBART \& M SCHUH (2000) A reconstruction of the invasion of land by Jamaican crabs. Journal of Zoology, London 250: 141-160.

DOLLARD HA (1980) Larval release patterns in the wharf crab Sesarma cinereum from North Inlet, South Carolina. MSc. Thesis, Department of Biology, University of South Carolina, Columbia, South Carolina, USA. vii +39 pp.

EIPFANIO CE (1988) Transport of invertebrate larvae between estuaries and the continental shelf. Transactions of the American Fisheries Society Symposium Series 3: 104-114.

FORWARD RB JR (1988) Larval release rhythms of decapod crustaceans: an overview. Bulletin of Marine Science 41: 165-176.

HOVEL KA \& SG MORGAN (1997) Planktivory as a selective force for reproductive synchrony and larval migration. Marine Ecology Progress Series 157: 7995.

IMS RA (1990) The ecology and evolution of reproductive synchrony. Trends in Ecology \& Evolution 5: 135140.

KELLMEYER K \& M SALMON (2001) Hatching rhythms of Uca thayeri Rathbun: timing in semidiurnal and mixed tidal regimes. Journal of Experimental Marine Biology and Ecology 260: 169-183.

LARDIES MA \& JC CASTILLA (2001) Latitudinal variation in the reproductive biology of the commensal crab Pinnaxodes chilensis (Decapoda Pinnotheridae) along the Chilean coast. Marine Biology 139: 11251133 .

LESSIOS H (1991) Presence and absence of monthly reproductive rhythms among eight Caribbean echinoids off the coast of Panama. Journal of Experimental Marine Biology and Ecology 153: 27-47.

LEVITAN DR (1991) Influence of body size and density on fertilization success and reproductive output in a free-spawning invertebrate. Biological bulletin 181: 261-268.

LEVITAN DR (1998) Sperm limitation, gamete competition and sexual selection in external fertilizers. In: Birkhead T \& A Møller (eds) Sperm competition and sexual selection: 173-215. Academic Press, New York, New York, USA.

MORGAN SG (1987a) Adaptive significance of hatching rhythms and dispersal patterns of estuarine crab larvae: avoidance of physiological stress by larval export? Journal of Experimental Marine Biology and Ecology 113: 71-78.

MORGAN SG (1987b) Behavioral and morphological antipredator adaptations of decapod zoeae. Oecologia 73: 393-400.

MORGAN SG (1989) Adaptive significance of spination in estuarine crab zoeae. Ecology 70: 464-482.

MORGAN SG (1990) Impact of planktivorous fishes on dispersal, hatching and morphology of estuarine crab larvae. Ecology 71: 1639-1652. 
MORGAN SG (1995) The timing of larval release. In: McEdward L (ed) Ecology of marine invertebrate larvae: 157-191. CRC Press, Boca Raton, Florida, USA.

MORGAN SG \& JH CHRISTY (1994) Species-Specific hierarchies of rhythms regulating reproductive timing: plasticity, constraint and optimality in larval release. Ecology 70: 462-482.

MORGAN SG \& JH CHRISTY (1995) Adaptive significance of the timing of larval release by crabs. American Naturalist 145: 457-479.

MORGAN SG \& JH CHRISTY (1996) Survival of marine larvae under countervailing selective pressures of photodamage and predation. Limnology and Oceanography 41: 498-504.

MORGAN SG \& JH CHRISTY (1997) Planktivorous fishes as selective agents for reproductive synchronony. Journal of Experimental Marine Biology and Ecology 209: 89-101.sal on

SAIGUSA M (1981) Adaptive significance of semilunar rhythm in the terrestrial crab Sesarma. Biological Bulletin 160: 311-321

SAIGUSA M (1988) Entrainment of tidal and semilunar rhythms by artificial moonlight cycles. Biological Bulletin 147: 126-138.

SANDIFER PA (1973) Distribution and abundance of decapod crustacean larvae in the York River estuary and adjacent lower Chesapeake Bay, Virginia 19681969. Chesapeake Science 14: 235-257.

Associate Editors: Patricio Ojeda and Luis Ebensperger Received October 7, 2002; accepted March 11, 2003
SANDIFER PA (1975) The role of pelagic larvae in recruitment to populations of adult decapod crustaceans in the York River estuary and adjacent lower Chesapeake Bay, Virginia. Estuarine and Coastal Marine Science 3: 269-279.

STRATHMANN RR (1982) Selection for retention or export of larvae in estuaries. In: Kennedy VS (ed) Estuarine comparisons: 521-536. Academic Press, New York, New York, USA.

VERNBERG FJ \& WB VERNBERG (1975) Adaptations to extreme environments In: Vernberg FJ (ed) Physiological ecology of estuarine organisms: 165-180. University of South Carolina Press, Columbia, South Carolina, USA.

VON HAGEN HO (1970) Anpassungen an das spezielle Gezeitensonen-Niveau bei Ocypodiden (Decapoda, Brachyura). Forma et Functio 2: 361-413.

WEAR RG (1974) Incubation in British decapod Crustacea and the effects of temperature on the rate and success of embryonic development. Journal of the Marine Biological Association of the United Kingdom 54: 745-762.

WHEELER DE (1978) Semilunar hatching periodicity in the mud fiddler crab Uca pugnax (Smith). Estuaries 1: 268-269.

ZUCKER N (1978) Monthly reproductive cycles in three sympatric hood-building tropical fiddler crabs (genus Uca). Biological Bulletin 155: 410-424. 